medRxiv preprint doi: https://doi.org/10.1101/2020.07.29.20164426; this version posted July 31, 2020. The copyright holder for this preprint (which was not certified by peer review) is the author/funder, who has granted medRxiv a license to display the preprint in perpetuity.

All rights reserved. No reuse allowed without permission.

Title Page

Type: Original Article

Title: Prevalence of Iron, Vitamin B12 deficiency and inflammatory anaemia in treatment naive individual consecutive cancer patients: A cross sectional study.

Authors: Pandey A, Singh S,Aryan R, Murari K,

Department of Medical Oncology, State Cancer Institute, Indira Gandhi Institute of Medical Sciences, Patna, Bihar, India

Running title: Prevalence of anaemia in pre treatment cancer patients

\title{
Corresponding Author,
}

Avinash Pandey,

Assistant Professor and In-charge, Department of Medical Oncology, State Cancer Institute, IGIMS, Patna

Email Address: dr.avinashp9@gmail.com

Phone number:(+91)- 7634931217

Address

Room Number 83,84

Department of Medical Oncology, IGIMS, State Cancer Institute, Patna.

\section{Acknowledgements:}

1. Dr. Ruchi Kapoor, Oncquest Laboratories, New Delhi, India.

Disclosures : None

Financial support: None 
medRxiv preprint doi: https://doi.org/10.1101/2020.07.29.20164426; this version posted July 31,2020 . The copyright holder for this preprint (which was not certified by peer review) is the author/funder, who has granted medRxiv a license to display the preprint in perpetuity.

All rights reserved. No reuse allowed without permission.

\section{Title: Prevalence of Iron, Vitamin B12 deficiency and inflammatory anaemia in treatment naive individual consecutive cancer patients: A cross sectional study.}

Background: In treatment naive Indian cancer patients, prevalence of iron, B12 deficiency and inflammatory anaemia in poorly known.

Aims and Objectives : To evaluate prevalence of anaemia and iron, B12 deficiency along with inflammation in treatment naive individual consecutive cancer patients.

Material and Methods: All patients registered from 1st July 2019 till 31st December 2019 in Medical Oncology Outpatient Department were offered to undergo Iron profile, Serum B12 levels and Serum ferritin along with routine haematological investigations. Anaemia was defined as Haemoglobin $<11 \mathrm{gm} / \mathrm{dL}$. Transferrin saturation $<20 \%$, Serum Ferritin $>300$ microgram/litre and Vitamin B12 level <200 picogram/millilitre were 'cut-offs' used to define iron deficiency, inflammation and Vitamin B12 deficiency respectively. Data was analysed using descriptive statistics, frequency distribution, crosstabs and Bar Diagram in SPSS version 17.0. Pearsons Chi square test and Odds ratio was used to measure the strength of association with variables.

Results: $311 / 441$ (70.5\%) were found eligible. Median age was $52 \pm 15.9$ (Range 18-84 ) years with $144 / 331(46 \%)$ females. The prevalence of anaemia was $61 \% \pm 2.7(95 \% \mathrm{Cl} 55-$ $66 \%$ ). Mean Haemoglobin was $9.86 \pm 2.08$ (range 3-16) gram/decilitre. 21/311(7\%) had severe anaemia (Haemoglobin < $6.9 \mathrm{gm} / \mathrm{dl}$ ). 135/311 (71\%), 61/189 (32\%) and 89/189 (47\%) anaemic patients had iron deficiency, inflammation and B12 deficiency respectively. More than 70\% of Gastrointestinal (50/69), Gynaecological(17/24) and Lung Cancer(18/22) patients had underling Iron deficiency.

Conclusion: Two-third of cancer patients are iron deficient. B12 deficiency and inflammation are present in half and one-third patients respectively.

Keywords: Iron deficiency, B12 deficiency ,Inflammatory Anaemia, Cancer Anaemia.

\section{Introduction}

Higher prevalence of anaemia in cancer is associated with inferior outcomes, including poor survival and inferior quality of life. ${ }^{1-3}$ Blood loss, malnutrition, haemolysis, chronic inflammation, bone marrow suppression or decreased erythropoeisis, all can individually or in unison cause drop in haemoglobin among cancer patients. ${ }^{3,4}$ Treatment with chemotherapy or radiotherapy can further compromise red blood cell mass and advanced stage tumours have often higher prevalence of anaemia. ${ }^{4,5}$ Further, distribution of anaemia among cancer patients may vary considerably across different countries and hence need to be studied individually, specific to local population cohort. ${ }^{6-8}$ 
medRxiv preprint doi: https://doi.org/10.1101/2020.07.29.20164426; this version posted July 31,2020 . The copyright holder for this preprint (which was not certified by peer review) is the author/funder, who has granted medRxiv a license to display the preprint in perpetuity.

All rights reserved. No reuse allowed without permission.

Most of the studies published have primarily focussed on iron deficiency component of cancer anaemia and subsequent remedial therapeutic options, including iron supplementation and blood transfusions. ${ }^{2,6-8}$ A more comprehensive effort with other possible co-variables, such as vitamin deficiencies and chronic inflammation apart from iron deficiency is merited to discover other salient but inconspicuous causes of pre- treatment cancer anaemia, preferably prospectively. We report an Indian prospective cross sectional study among treatment naive, newly diagnosed adult individual consecutive patients across several subtype of malignancies and report underlying iron, vitamin B12 deficiency and chronic inflammation, irrespective of haemoglobin status.

\section{Material and Methods}

\section{A. General Study details}

This is a prospective cross- sectional study of individual consecutive treatment naive adult cancer patients registered in Department of Medical Oncology at Regional Cancer Centre, Indira Gandhi Institute of Medical Sciences, Patna from 1st July, 2019 till 31st December 2019. It is a non interventional, observational study with aim to illicit the prevalence of anaemia, Iron- B12 deficiency and chronic inflammation before receiving any cancer directed therapy. Written informed consent was obtained from each participant before enrolment. Apart from routine pre-treatment work up investigations such as Complete Hemogram, serology, coagulation profile, renal and hepatic function tests, we also obtained peripheral venous blood samples for Serum Iron, Serum Ferritin, Total Iron Binding Capacity, transferrin saturation and serum B12 levels. The study was conducted in accordance with Declaration of Helsinki and the Indian Council of Medical Research (ICMR) guidelines for ethical conduct. ${ }^{9}$ No funding was received for the conduct of the study.

\section{B. Eligibility Criteria}

All adults of age more than 18 years, irrespective of type of malignancy were eligible for this study. Patients enrolled should have cytology, biopsy, serological, tumour markers or flow cytometry based confirmation of malignancy and its type either at the time of enrolment or soon after (within 2 weeks). Any patient who has received prior anti-cancer therapy including chemotherapy, hormonal, radiotherapy or major surgery, except diagnostic biopsy/ cytology were excluded. Patients found pregnant, with chronic renal failure failure, decompensated liver cirrhosis, inflammatory bowel diseases, history of major gastric or bowel resection, active life threatening infection, chronic active infection e.g Tuberculosis, Leishmaniasis, active rheumatological or flared up connective tissue disorders such as Rheumatoid arthritis, spondyloarthropathies, Systemic Lupus Erythromatosis, scleroderma or sarcoidosis were excluded. 
medRxiv preprint doi: https://doi.org/10.1101/2020.07.29.20164426; this version posted July 31,2020 . The copyright holder for this preprint (which was not certified by peer review) is the author/funder, who has granted medRxiv a license to display the preprint in perpetuity.

All rights reserved. No reuse allowed without permission.

Patients with documented psychiatric condition interfering with diet such as anorexia nervosa or bulimia were excluded. Any patient with history of prior prescription of oral / parenteral iron or B12 supplementation in past three months were not considered. Any history of blood transfusion in past one month were excluded. Patients with history of chronic gastrointestinal bleed, including any tumour related events such as bleeding per vaginum or hemoptysis, hematemesis or heamaturia were however eligible to participate.

\section{c. Sample collection and processing}

'Three milliliters blood sample was drawn from an accessible peripheral vein in aplastic tube with or without gel barrier [red or yellow-top serum separator vacutainer] irrespective of fasting or special dietary requirements. Serum was removed from the red blood cell clot and stored at $2^{\circ} \mathrm{C}-8^{\circ} \mathrm{C}$ refrigeration, if the sample could be processed on the same day or was frozen and stored at $-20^{\circ} \mathrm{C}$ if processing was delayed. Care to be taken to exclude any sample with gross hemolysis, fibrin, or particulate matter. Samples once thawed were mixed thoroughly by low-speed vortexing or by inverting ten times. Specimens were centrifuged for $3000 \mathrm{rpm}$ for $10 \mathrm{~min}$ in centrifugation tubes to maintain consistency in results. Only clear samples withoutbubbles were transferred after centrifugation for further processing. For sample processing, Glass tubes were not tested. The average turnaround time for reports was $24-48$ hours.

a. For Serum Iron estimation: The MULTIGENT iron assay was used which is intended for the direct colorimetric determination of iron without deproteinization in human serum on the ARCHITECT cSystems. The iron Assay is standardized against National Institute of Standards and Technology Standard Reference Material 3126

b. For Serum Ferritin Levels: The ARCHITECT Ferritin assay was used which is a chemiluminescent microparticle immunoassay [CMIA] for the quantitative determination of ferritin in human serum onARCHITECT iSystems. The Ferritin Assay is standardized against the World Health Organization (W.H.O.) Ferritin First International Standard 80/602

c. For Transferrin: The Transferrin assay was used which is an immunoturbidimetric procedure for determination of transferrin in human serum on the ARCHITECT cSystems. The Transferrin Assay is standardized against reference method calibrated against ERMDA470.80/602.

d. For serum B12 levels: The ARCHITECT B12 assay was used which is a Chemiluminescent Microparticle Intrinsic Factor assay for the quantitative determination of vitamin B12 in human serum on the ARCHITECT iSystem. Abbott manufactures B12 internal standards gravimetrically using Cyanocobalamin (USP Reference Standard). The B12 calibrators are manufactured and tested against these internal standards. 
medRxiv preprint doi: https://doi.org/10.1101/2020.07.29.20164426; this version posted July 31,2020 . The copyright holder for this preprint (which was not certified by peer review) is the author/funder, who has granted medRxiv a license to display the preprint in perpetuity.

All rights reserved. No reuse allowed without permission.

\section{Data collection, sample size and Definition}

Demographic data including age, sex, type of malignancy, stage were recorded. Anaemia was classified as per definition of Indian Council of Medical Research (ICMR) into Mild Anaemia (Haemoglobin 10.9 -10 gram/decilitre), Moderate Anaemia (Haemoglobin 9.97 gram/decilitre), Severe Anaemia (Haemoglobin 6.9- 4 gram/decilitre), Very Severe (Haemoglobin less than 4 gram/decilitre). Anaemia was also classified as per Mean Corpuscular Volume into Microcytic (< 79.9 femtolitres), Normocytic (80-100 femtolitres) and Macrocytic ( >100.1 femtolitres) anaemia. The formal sample size calculation was not done and all the patients in the defined time period from 1st July 2019 till 31st December 2019 were assessed for eligibility into the study. Patients for whom iron profile and B12 level estimation was ordered but the reports were not traceable due to technical failure or not reported $(n=18)$ were classified as data Missing completely at random (MCAR). This missing data was subject to Listwise deletion for complete case analysis making the final sample size of 311. As a result of this, the estimated parameters including prevalence of anaemia are not biased by the absence of the such missed data.

To maintain uniformity in methods of assessment we defined Iron deficiency as those patients having transferrin saturation less than $20 \%$. Patients were classified to have inflammatory state if their serum ferritin levels were more than 300 microgram/litre. Vitamin B12 was defined as low when serum B12 levels were less than 200 picogram/millilitre. All patients were categorised as iron deficient, B12 deficient and in inflammatory state irrespective of having anaemia or not, using above definitions.

\section{E. Patient Management Protocol}

Our threshold for Packed cell transfusion was less than 7.0 gram per decilitre of haemoglobin, unless impending cardiac, renal morbidity, major active bleeding, clinical decision or sepsis merited to reduce transfusion threshold. At the time of recording haematological reports (within two weeks of registration), including complete haemogram, iron profile and serum B12 levels, patients who were anaemia and had Iron or B12 deficiency were given option to receive supplementation. Patients were prescribed either intravenous injectable ferric carboxymaltose (1000 mg flat dose) or ferrous sulfate capsules (100 mg) three times a day for a month. None of the patients were prescribed Erythropoeitin Stimulating Agents (ESA). Similarly for B12 deficient anaemia ,1000 microgram of cyanocobalamine intramuscular injection once daily for seven days, then weekly for one month, then monthly for 6 months were prescribed. However, patients were not followed to check compliance or change in haemoglobin, as this was beyond the purview of study. We did not define or measured any clinical, haematological or serological endpoint for later follow up, irrespective of deficient store replenishment status, as this was a single point cross sectional study of prevalence only.

\section{F. Statistics}


medRxiv preprint doi: https://doi.org/10.1101/2020.07.29.20164426; this version posted July 31,2020 . The copyright holder for this preprint (which was not certified by peer review) is the author/funder, who has granted medRxiv a license to display the preprint in perpetuity.

All rights reserved. No reuse allowed without permission.

All data were recorded in real time in the Outpatient Department of Medical Oncology by a trained data entry operator under the supervision of the physician. Descriptive statistics, including tables, Venn diagram, charts and frequency distribution, were derived from SPSS software version 17.0 (IBM Corp. Released 2017. IBM SPSS Statistics for Windows, version 17.0. Armonk, NY, USA). Pearsons Chi Square test was used to analyse association of anaemia with several relevant categorical variables. Odds ratio was calculated to measure the strength of association, if any using above software.

\section{Results}

\section{A. Patient characteristics}

Out of 441patients screened and offered baseline Iron profile and serum B12 estimation, only 311 were finally enrolled in the study. [see FLOW diagram, Fig1]. Median age at diagnosis was $52 \pm 15.9$ (range 18-84). 167 (54\%) were males. 79\% had advanced stage III/IV cancers and $19 \%$ had haematological malignancies. Mean Haemoglobin of entire population was $9.86 \pm 2.08$ (range $3-16$ ). See Table 1 .

\section{B. Anaemia profile}

The prevalence of anaemia in treatment naive cancer patients was $61 \% \pm 2.7$ (95\% Cl 55-66\%). [See Table 2]. 135/311 (71\%), 61/189 (32\%) and 89/189 (47\%) anaemic patients had iron deficiency, inflammation and B12 deficiency respectively. See [Table 3]. The prevalence of anaemia across several major sites/types of cancers was $71 \%$ (42/59) in haematolymphoid, 58\% (40/69) Gastrointestinal malignancies,59\%(35/59) Breast cancer,68\% (24/35) Gall bladder cancer, 66\% (16/24) Gynaecological cancer and 50\% $(11 / 22)$ in Lung cancers. More than $70 \%$ of Gastrointestinal (50/69), Gynaecological(17/24) and Lung Cancer(18/22) patients had underling Iron deficiency. [See Fig 2]. There was considerable overlap with patients having concurrent iron deficiency, B12 insufficiency and chronic inflammation. 16/311 (5\%) of patients had all above three combined. See Venn diagram [see Fig 3]

\section{Association of variables with anaemia}

Iron deficiency was strongly associated with anaemia with Pearson Chi square value of $8.05(p=0.005)$ and Odds ratio of 1.98 ( $95 \% \mathrm{Cl}-1.23-3.195)$. Similarly, chronic inflammation was significantly associated with anaemia with above value as 4.13 $(p=0.042)$ and Odds ratio of $1.72(95 \% \mathrm{Cl}-1.02-2.90)$. Females had higher probability of anaemia with Pearson Chi square value of 4.90 ( $p=0.027)$ and Odds ratio of 1.67 (95\% Cl1.06-2.65) compared to males. Underlying B12 deficiency was not associated with anaemia in terms of statistical significance with Pearson value of $2.48(p=0.115)$ and Odds ratio of 1.45 (95\% Cl 0.91- 2.30). Similarly, neither higher age (more than 60 years or less) nor type of malignancy (haematological or solid cancers) had shown significant association with respect to anaemia status. 
medRxiv preprint doi: https://doi.org/10.1101/2020.07.29.20164426; this version posted July 31,2020 . The copyright holder for this preprint (which was not certified by peer review) is the author/funder, who has granted medRxiv a license to display the preprint in perpetuity.

All rights reserved. No reuse allowed without permission.

\section{Supplementation for anaemia}

Out of 21 patients with haemoglobin less than 7 gram per decilitre, blood transfusion was administered in 19 (90\%) within two weeks of getting registered, while one patient declined and another defaulted. 122/135 (90\% ) were prescribed iron supplementation, while nine declined, three defaulted and one died by second week of registration. Among patients who received iron supplementation, 84/122 (69\%) received intravenous iron along with intravenous chemotherapy, while 38/122 (31\%) preferred oral iron capsules. Only 58/89 (65\%) with B12 deficient anaemia received intramuscular cyanacobalmine for at least seven days of prescription, while $19 / 89(21 \%)$ received less than seven days and another 12 declined for it.

\section{Discussion}

We report the results of our prospective cross sectional study to evaluate the prevalence of anaemia in adult treatment naive individual consecutive Indian cancer patients. The prevalence of anaemia was $61 \% \pm 2.7$ (95\% Cl 55-66\%) with mean haemoglobin of entire population of $9.86 \pm 2.08$ (range $3-16$ ). $71 \%, 32 \%$ and $47 \%$ anaemic patients had underlying iron deficiency, inflammation and B12 deficiency respectively. More than $70 \%$ of Gastrointestinal, Gynaecological and Lung Cancer patients had underling Iron deficiency. As per the best of knowledge of authors, this is the first prospective cross sectional study in individual consecutive adult patients across several types of malignancies from India to report the prevalence of underlying pre- treatment anaemic status.

In one of the largest prospective observational study conducted in twenty four European countries with 15367 cancer patients spread across 248 centres, the prevalence of anaemia at enrolment before cancer directed therapy was $31.7 \%{ }^{10}$ They defined anaemia as haemoglobin less than 12.0 gram per decilitre as per American Society of Clinical Oncology and Common Toxicity Criteria, National Cancer Institute $(\mathrm{NCl})^{11,12}$. They showed presence of anaemia in more than $70 \%$ of patients with lung cancers or Gynaecological malignancies either at baseline or at some time point within six months of enrolment, including treatment period. ${ }^{10}$ In another observational study reported from Italy and Austria, with Haemoglobin cut off of 10.0 gram per decilitre, the prevalence of anaemia was $32 \% .^{7}$ Majority of patients (80\%) had solid malignancies and $13 \%$ had used Erythropoeitin Stimulating Agents (ESA) for resolution of symptoms. Both above studies, also mention use of Iron (oral or intravenous) supplementation apart from blood transfusion and ESA for patients with anaemia. However, none of the above two large studies report the baseline iron stores, serum ferritin levels as marker of inflammation or serum B12 levels 
medRxiv preprint doi: https://doi.org/10.1101/2020.07.29.20164426; this version posted July 31,2020 . The copyright holder for this preprint (which was not certified by peer review) is the author/funder, who has granted medRxiv a license to display the preprint in perpetuity.

All rights reserved. No reuse allowed without permission.

to establish the exact etiology and proportional role of above three elements in pathophysiology of anaemia in treatment naive cancer patients. There is paucity of similar comprehensive observational study evaluating prevalence of anaemia in treatment naive cancer patients from Indian subcontinent.

Anaemia prevalence varies widely across different continents and countries. World Health Organisation (WHO) estimates the prevalence of anaemia among general healthy population as $23 \%$ in Europe, while $45-47 \%$ among Africans and South East Asians. ${ }^{13}$ In India, the prevalence of anaemia also differs among different high risk groups such as Pre-school children (74\%), School girls (50\%) and pregnant women (52\%). ${ }^{13,14}$ Hence , it is pertinent to have country or state specific prospective study to illicit anaemia prevalence, especially among high risk group such as newly diagnosed cancer patients. Few attempts have been made across various cancers in India and reported prospectively. In a study done among 96 newly diagnosed and treatment naive lung cancer patients reported from single centre in South India, the anaemia prevalence was $61.4 \%{ }^{15}$ In another large prospective study done exclusively in newly diagnosed lymphoid malignancies with 316 patients recruited over eighteen months, the prevalence of anaemia was $42.4 \%{ }^{16}$ Nutritional deficiency as the cause was seen in less than half of anaemic cancer patients.

In the Regional Cancer Centre(RCC) of our institute, medical oncology department is a single faculty and single point of contact for all solid and haematological malignancies registered for receiving chemotherapy. ${ }^{17}$ This provide a unique vantage point with 'bird's eye view' across several subtypes of cancer treated under one roof, unlike many apex cancer centres where site and sub-site super-specialization conforms to restricted and diverse disease management patient pool. Our prospective observational cross sectional study includes 311 individual consecutive adult cancer patients of all major sites/types of cancer. We report the prevalence of anaemia as $61 \%$. This is in accordance with our previous published prospective study in treatment naive cancer patients, where prevalence of Vitamin D deficiency was $67 \% .{ }^{18,19}$ Both these highlight poor nutrition as the major factor behind cancer anaemia and Vitamin D deficiency.

In our study, haematolymphoid malignancies had higher number of patients with underlying anaemia at presentation (71\%).In absence of haematology department, majority of haematolymphoid malignancies are seen by medical oncology unit here, which in current study constitutes $19 \%(59 / 311)$ of all cases. ${ }^{20,21}$ Gall bladder is the most common cancer in this part of India. ${ }^{22}$ Gall bladder and gastrointestinal malignancies in our study, had $68 \%$ and $58 \%$ anaemia at presentation respectively. Compared to European studies, one of the reason for higher anaemia prevalence was presentation with more advanced stage, III and IV cancers $(79 \%, 245 / 311)$ in our patient population, which reflects late presentation and aggressive biology $7,10,23$.

There were several limitations of our study. We only measured the laboratory values of haemoglobin, iron profile and serum B12 levels, but did not illicit the 
medRxiv preprint doi: https://doi.org/10.1101/2020.07.29.20164426; this version posted July 31,2020 . The copyright holder for this preprint (which was not certified by peer review) is the author/funder, who has granted medRxiv a license to display the preprint in perpetuity.

All rights reserved. No reuse allowed without permission.

nature, type or severity of symptoms related to cancer anaemia such as fatigue, anorexia, breathlessness, palpitation or bleeding. As it was non interventional study, the decision to take iron or B12 supplementation was patient's discretion and was not controlled, directed or followed by our team. Being a single point cross sectional study, we did not followed up patients longitudinally to study further drop in Haemoglobin with cancer directed therapies or extend of rise of haemoglobin and time taken to improve anaemic status after any supplementation. This is also the reason that we could not analyse treatment response, toxicities, outcomes or survival across several malignancies with respect to anaemia status at baseline.

Our study is a single largest institutional analysis reporting prevalence of anaemia in Eastern India, however this may not be a representative sample with respect to major metropolitan cities, West and South India. In our study target population was strictly defined as per the eligibility criteria, hence generalizability and external validity of our result beyond defined population cannot be guaranteed especially with respect to diverse geographical, temporal and ethical conditions. In a retrospective clinical audit done before finalising protocol for current study, it came to our notice that serum folate levels were not, reported consistently by our institutional laboratory. On further exploration we discovered that procurement and supply chain of folate assays were inconsistent due to several logistical issues leading to scarce reporting. Hence, we did not include serum folate measurements in our prospective study. Moreover, exclusive folate deficiency with normal B12 levels alone as cause of anaemia is seen in less than $2 \%$ of cancer patients. ${ }^{16}$ However, a separate comprehensive study is merited to evaluate its independent significance in treatment naive cancer patients with underlying anaemia.

\section{Conclusion}

Anaemia is prevalent in sixty percent of treatment naive adult cancer patients. Iron deficiency, B12 deficiency and chronic inflammatory state are seen in twothird, half and one-third patients respectively. Identifying cause of anaemia at presentation, including nutritional deficiencies, may improve anaemic status after supplementation. Whether such pre-treatment probing of deficiencies and their subsequent correction impacts cancer outcomes and treatment toxicities favourably needs to be explored prospectively further.

\section{References}

1. Caro JJ, Salas M, Ward A, Goss G. Anemia as an independent prognostic factor for survival in patients with cancer: a systematic, quantitative review. Cancer. 2001;91(12):2214-21.

2. Kanuri G, Sawhney R, Varghese J, Britto M, Shet A. Iron deficiency anemia coexists with cancer related anemia and adversely impacts quality of life. PloS one. 2016;11(9):e0163817. 
medRxiv preprint doi: https://doi.org/10.1101/2020.07.29.20164426; this version posted July 31,2020 . The copyright holder for this preprint (which was not certified by peer review) is the author/funder, who has granted medRxiv a license to display the preprint in perpetuity.

All rights reserved. No reuse allowed without permission.

3. Lind M, Vernon C, Cruickshank D, Wilkinson P, Littlewood T, Stuart N, et al. The level of haemoglobin in anaemic cancer patients correlates positively with quality of life. British journal of cancer. 2002;86(8):1243-9.

4. Harrison LB, Shasha D, White C, Ramdeen B. Radiotherapy-associated anemia: the scope of the problem. The oncologist. 2000; 5(90002):1-7.

5. Rodgers GM, Becker PS, Blinder M, Cella D, Chanan-Khan A, Cleeland C, et al. Cancer-and chemotherapy-induced anemia. Journal of the National Comprehensive Cancer Network. 2012; 10(5):628-53.

6. Bach V, Schruckmayer G, Sam I, Kemmler G, Stauder R. Prevalence and possible causes of anemia in the elderly: a cross-sectional analysis of a large European university hospital cohort. Clinical interventions in aging. 2014;9:1187.

7. Merlini L, Cartenì G, lacobelli S, Stelitano C, Airoldi M, Balcke P, et al. Anemia prevalence and treatment practice in patients with non-myeloid tumors receiving chemotherapy. Cancer management and research. 2013;5:205.

8. Prabhash K, Nag S, Patil S, Parikh PM. Optimising management of cancer related anemia. Indian journal of cancer. 2011; 48(1):1.

9. Indian Council of Medical Research. Evaluation of the National Nutritional Anaemia Prophylaxis Programme. Task Force Study. New Delhi: ICMR, 1989.

10. Ludwig H, Van Belle S, Barrett-Lee P, Birgegård G, Bokemeyer C, Gascón P et al. The European Cancer Anaemia Survey (ECAS): a large, multinational, prospective survey defining the prevalence, incidence, and treatment of anaemia in cancer patients. European journal of cancer. 2004; 40(15):2293-306.

11. Rizzo JD, Lichtin AE, Woolf SH, et al. Use of epoetin in patients with cancer: evidencebased clinical practice guidelines of the American Society of Clinical Oncology and the American Society of Hematology. J Clin Oncol 2002; 20: 4083-4107.

12. Cancer Therapy Evaluation Program. Common Toxicity Criteria, Version 2.0. DCTD, NCl, NIH, DHHS. March 1998; published 1999.

13. World Health Organization. Worldwide prevalence of anaemia 1993-2005: WHO global database on anaemia.

14. Kumari R, Bharti RK, Singh K, Sinha A, Kumar S, Saran A, et al. Prevalence of iron deficiency and iron deficiency anaemia in adolescent girls in a tertiary care hospital. Journal of clinical and diagnostic research: JCDR. 2017;11(8):BC04. 
medRxiv preprint doi: https://doi.org/10.1101/2020.07.29.20164426; this version posted July 31,2020 . The copyright holder for this preprint (which was not certified by peer review) is the author/funder, who has granted medRxiv a license to display the preprint in perpetuity.

All rights reserved. No reuse allowed without permission.

15. Baburao A, Narayanswamy H. Clinico-pathological profile and haematological abnormalities associated with lung cancer in Bangalore, India. Asian Pacific Journal of Cancer Prevention. 2016;16(18):8235-8.

16. Ghosh J, Singh RK, Saxena R, Gupta R, Vivekanandan S, Sreenivas V, et al. Prevalence and aetiology of anaemia in lymphoid malignancies. Natl Med J India. 2013; 26(2):79-81.

17. Pandey A, Singh A, Singh S, Kumar A. Patient-doctor ratio across nine super speciality clinics in government hospital: A cross sectional study. Int J Community Med Public Health 2019;6:4421.

18. Pandey A, Singh A, Singh S. Prevalence of Vitamin D deficiency in treatment-naive individual consecutive cancer patients. Cancer Research, Statistics, and Treatment. 2020; $3(1): 25$.

19. Pandey A. Author reply to Shamsi et al. and Vora. Cancer Research, Statistics, and Treatment. 2020; 3(2):372

20. Pandey A, Ahlawat S, Singh A, Singh S, Murari K, Aryan R. Outcomes and impact of minimal residual disease (MRD) in pediatric, adolescent and young adults (AYA) with acute lymphoblastic leukemia treated with modified MCP 841 protocol. Cancer Research, Statistics, and Treatment. 2020; 3(2):183.

21. Pandey A, Deshpande P, Singh A, Singh S, Murari K, Aryan R. Oral Prednisolone, Etoposide, 6-Mercaptopurine (PREM) metronomic chemotherapy in treatment naïve and partially treated acute myeloid leukemia in a resource constrained setting. Cancer Research, Statistics, and Treatment. 2020; 3(2):172.

22. PandeyA, Raj S, Madhawi R, Devi S, Singh RK. Cancer trends in Eastern India:

Retrospective hospital-based cancer registry data analysis. South Asian J Cancer 2019;8:2157

23. Pandey A, Singh A, Singh S, Shahi H, Kumar A, Kumari A, Das A. First physician of contact and time to presentation among rural adult cancer patients: A prospective survey. South Asian Journal of Cancer. 2019;60:61. 
Iron Profile, Vitamin B12 and Serum ferritin tests were offered to all consecutive treatment naive adult cancer patients $(\mathrm{N}=441)$

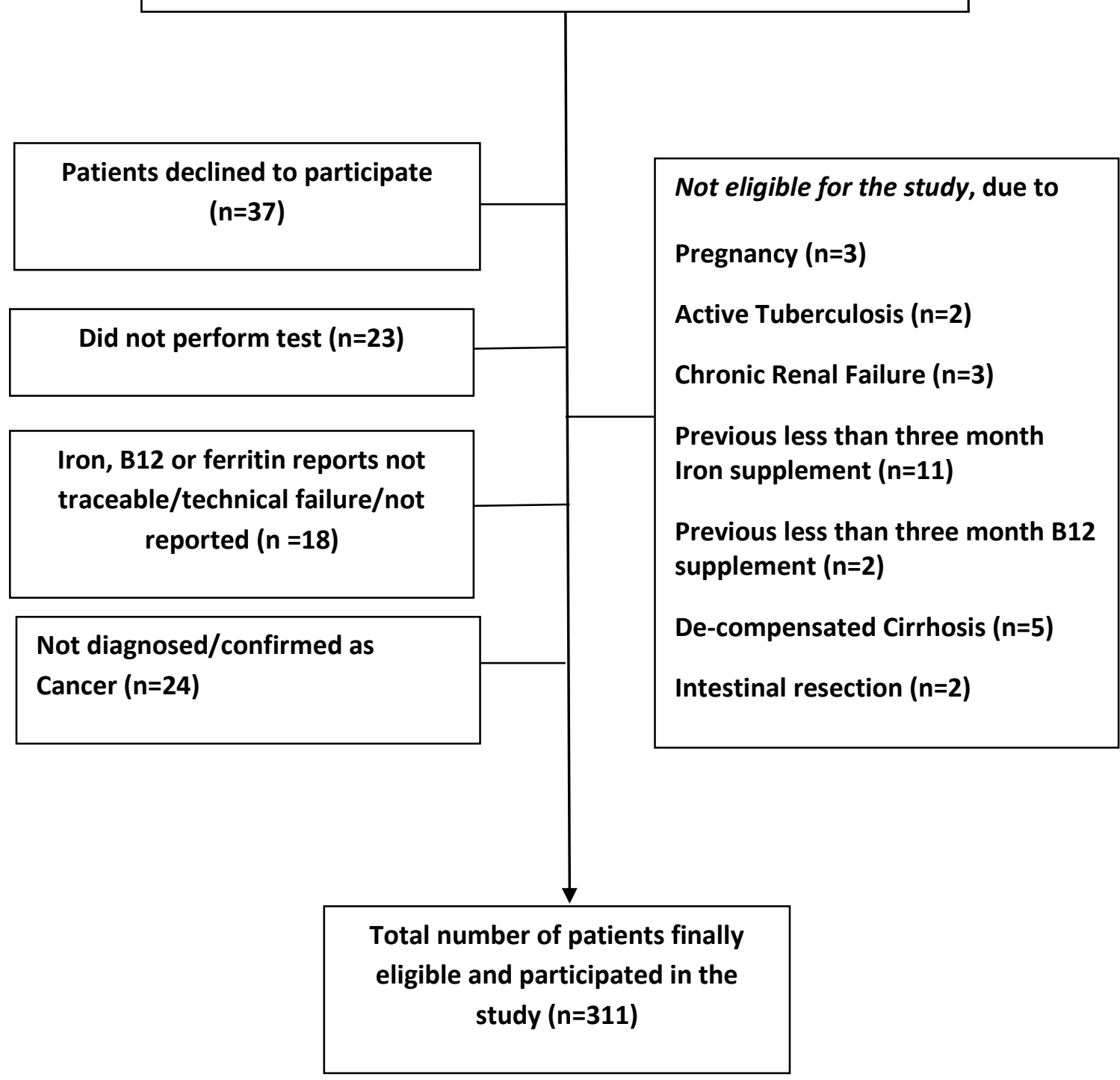

Figure 1. FLOW diagram showing the flowchart of participants accrual and eligibility for the study. 
medRxiv preprint doi: https://doi.org/10.1101/2020.07.29.20164426; this version posted July 31,2020 . The copyright holder for this preprint (which was not certified by peer review) is the author/funder, who has granted medRxiv a license to display the preprint in perpetuity.

All rights reserved. No reuse allowed without permission.

\begin{tabular}{|c|c|c|}
\hline Sr. No & Variables & Values \\
\hline 1. & Age in years (median) & $52 \pm 15.9($ range $18-84)$ \\
\hline \multirow[t]{3}{*}{2.} & Sex & \\
\hline & Male & $167(54 \%)$ \\
\hline & Female & $144(46 \%)$ \\
\hline 3 & Mean Haemoglobin (gram/ decilitre) & $9.86 \pm 2.08(3-16)$ \\
\hline \multirow[t]{4}{*}{4} & Haemoglobin Indices & \\
\hline & Mean Corpuscular Volume (MCV in femtolitre) & $87.6 \pm 9.96(61-126)$ \\
\hline & $\begin{array}{l}\text { Mean Corpuscular Haemoglobin Concentration } \\
\text { (MCHC in gram/decilitre) }\end{array}$ & $28.34 \pm 7.55(16.5-39)$ \\
\hline & $\begin{array}{l}\text { Mean Corpuscular Haemoglobin ( } \mathrm{MCH} \text { in } \\
\text { picogram/cell) }\end{array}$ & $31 \pm 4.64(20-39)$ \\
\hline \multirow[t]{5}{*}{5} & Iron Indices & \\
\hline & Mean Serum Iron (microgram/decilitre) & $50.53 \pm 29.8(5.5-208)$ \\
\hline & $\begin{array}{l}\text { Mean Total Iron Binding Capacity ( } \\
\text { microgram/decilitre) }\end{array}$ & $285.30 \pm 99.2(59-547)$ \\
\hline & Mean Serum Ferritin levels (microgram/litre) & $296.41 \pm 57.8(6.9-2131)$ \\
\hline & Mean Transferrin saturation (\%) & $19.04 \pm 11.34(2.5-63.1)$ \\
\hline 6 & Mean Vitamin B12 levels (picogram/millilitre) & $299.93 \pm 99.14(23-907)$ \\
\hline \multirow[t]{3}{*}{7} & Primary Site/ Type of Malignancies & \\
\hline & Head Neck & $12(3.9 \%)$ \\
\hline & Genitourinary & $20(6.4 \%)$ \\
\hline
\end{tabular}


medRxiv preprint doi: https://doi.org/10.1101/2020.07.29.20164426; this version posted July 31,2020 . The copyright holder for this preprint (which was not certified by peer review) is the author/funder, who has granted medRxiv a license to display the preprint in perpetuity.

All rights reserved. No reuse allowed without permission.

\begin{tabular}{|c|c|c|}
\hline & Central Nervous System & $2(0.6 \%)$ \\
\hline & Breast & $59(19 \%)$ \\
\hline & Lung & $22(7.1 \%)$ \\
\hline & Gastrointestinal & $69(22.2 \%)$ \\
\hline & Gall Bladder & 35 (11.3\%) \\
\hline & Gynaecological & $24(7.7 \%)$ \\
\hline & Haematolymphoid & $59(19 \%)$ \\
\hline & Sarcomas & $7(2.3 \%)$ \\
\hline & Miscellaneous & $2(0.6 \%)$ \\
\hline 8 & Stage of Cancer & \\
\hline & 1 & $4(1.28 \%)$ \\
\hline & II & $26(8.36 \%)$ \\
\hline & III & $105(33.7 \%)$ \\
\hline & IV & $140(45 \%)$ \\
\hline & Not applicable & 36 (11.5\%) \\
\hline
\end{tabular}

Table 1 .Demographic variables of patients enrolled in the study. 
medRxiv preprint doi: https://doi.org/10.1101/2020.07.29.20164426; this version posted July 31,2020 . The copyright holder for this preprint (which was not certified by peer review) is the author/funder, who has granted medRxiv a license to display the preprint in perpetuity.

All rights reserved. No reuse allowed without permission.

\begin{tabular}{|c|c|c|}
\hline Sr. No & Variables & Values (percentages) \\
\hline \multirow[t]{6}{*}{1} & Anaemia (Haemoglobin, $\mathrm{Hb}$ in gram/decilitre) & \\
\hline & No Anaemia ( $\mathrm{Hb} \geq 11.0)$ & $122(39.2 \%)$ \\
\hline & Mild Anaemia (Hb 10.9 -10) & $67(21.6 \%)$ \\
\hline & Moderate Anaemia ( Hb 9.9-7) & $101(32.5 \%)$ \\
\hline & Severe Anaemia (Hb 6.9 -4) & $19(6.1 \%)$ \\
\hline & Very Severe (Hb less than 4) & $2(0.6 \%)$ \\
\hline \multirow[t]{4}{*}{2} & Red Blood Cell Size (femtolitres) & \\
\hline & Microcytic (<79.9) & $67(21.5 \%)$ \\
\hline & Normocytic (80-100) & $220(70.7 \%)$ \\
\hline & Macrocytic ( >100.1) & $24(7.7 \%)$ \\
\hline \multirow[t]{4}{*}{3} & Serum Iron levels (microgram/decilitre) & \\
\hline & Less than 30 & $81(26 \%)$ \\
\hline & $30.1-100$ & $218(70 \%)$ \\
\hline & More than 100 & $12(4 \%)$ \\
\hline \multirow[t]{6}{*}{4} & Serum Ferritin Levels (microgram/litre) & \\
\hline & Less than 30 & $4(1.3 \%)$ \\
\hline & Between 30.1-100 & $12(3.9 \%)$ \\
\hline & Between 100.1-300 & $120(38.6 \%)$ \\
\hline & Between 300.1- 1000 & $58(18.6 \%)$ \\
\hline & More than 1000 & $117(37.6 \%)$ \\
\hline 5 & Transferrin saturation (\%) & \\
\hline
\end{tabular}


medRxiv preprint doi: https://doi.org/10.1101/2020.07.29.20164426; this version posted July 31,2020 . The copyright holder for this preprint (which was not certified by peer review) is the author/funder, who has granted medRxiv a license to display the preprint in perpetuity.

All rights reserved. No reuse allowed without permission.

\begin{tabular}{|l|l|l|}
\hline & Less than 16 & $153(49.2 \%)$ \\
\hline & Between 16.1 -20 & $51(16.4 \%)$ \\
\hline & Between 20.1-50 & $101(32.5 \%)$ \\
\hline 6 & Vitamin B12 levels (picogram/millilitre) & $6(1.9 \%)$ \\
\hline & Less than 30 & \\
\hline & Between 30.1-100 & $4(1.3 \%)$ \\
\hline & Between 100.1-200 & $12(3.9 \%)$ \\
\hline & Between 200.1-300 & $120(38.6 \%)$ \\
\hline & More than 300 & $58(18.6 \%)$ \\
\hline
\end{tabular}

Table 2. Anaemia and corresponding laboratory variables including iron profile and B12 values. 
medRxiv preprint doi: https://doi.org/10.1101/2020.07.29.20164426; this version posted July 31,2020 . The copyright holder for this preprint (which was not certified by peer review) is the author/funder, who has granted medRxiv a license to display the preprint in perpetuity.

All rights reserved. No reuse allowed without permission.

\begin{tabular}{|c|c|c|c|c|}
\hline Sr. No & Anaemia & $\begin{array}{l}\text { Iron deficiency } \\
\text { (Transferrin } \\
\text { saturation less } \\
\text { than } 20 \% \text { ) }\end{array}$ & $\begin{array}{l}\text { Inflammatory } \\
\text { (Serum Ferritin } \\
\text { more than } 300 \\
\text { microgram/litre) }\end{array}$ & $\begin{array}{l}\text { Low Vitamin B12 } \\
\text { levels ( Serum B12 } \\
\text { less than } 200 \\
\text { (picogram/millilitre) }\end{array}$ \\
\hline 1 & No anaemia $(n=122)$ & $69(56 \%)$ & $26(21 \%)$ & $47(38 \%)$ \\
\hline 2 & Mild Anaemia $(n=67)$ & $43(64 \%)$ & $19(28 \%)$ & $25(37 \%)$ \\
\hline 3 & Moderate Anaemia $(n=101)$ & $76(75 \%)$ & $35(35 \%)$ & $49(48 \%)$ \\
\hline 4 & Severe Anaemia $(n=19)$ & $14(74 \%)$ & $6(43 \%)$ & $13(68 \%)$ \\
\hline 5 & Very Severe $(n=2)$ & $2(100 \%)$ & $1(50 \%)$ & $2(100 \%)$ \\
\hline 6 & Total $*(n=189)$ & 135 (71\%) & $61(32 \%)$ & $89(47 \%)$ \\
\hline
\end{tabular}

Table 3. Anaemia status with respect to Iron deficiency, chronic inflammation and Vitamin B12 serum levels. 
medRxiv preprint doi: https://doi.org/10.1101/2020.07.29.20164426; this version posted July 31,2020 . The copyright holder for this preprint (which was not certified by peer review) is the author/funder, who has granted medRxiv a license to display the preprint in perpetuity.

All rights reserved. No reuse allowed without permission.

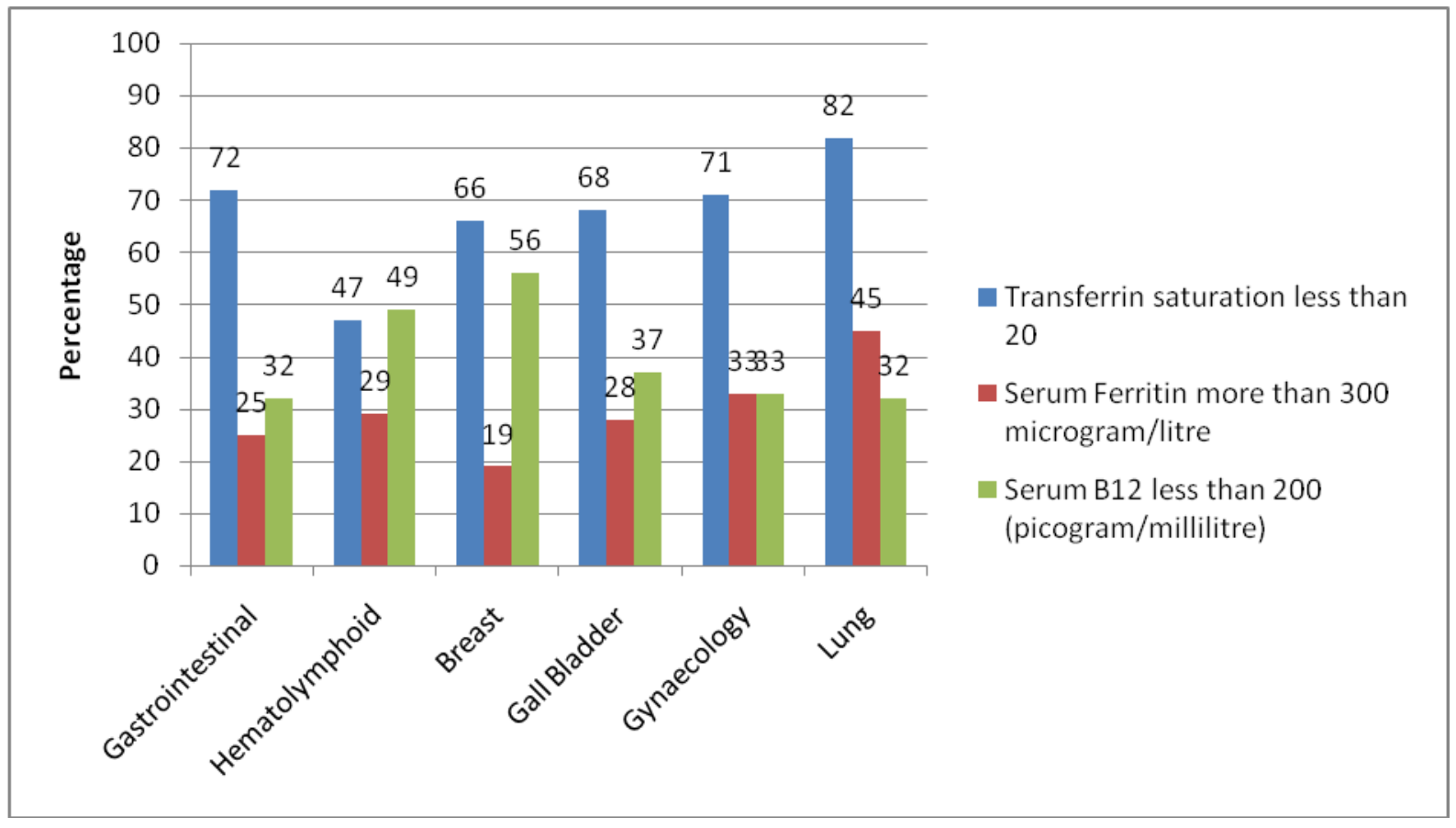

Figure 2. Percentage of patients with Iron deficiency, inflammation and B12 deficiency in several cancer types/sites. 
medRxiv preprint doi: https://doi.org/10.1101/2020.07.29.20164426; this version posted July 31,2020 . The copyright holder for this preprint (which was not certified by peer review) is the author/funder, who has granted medRxiv a license to display the preprint in perpetuity.

All rights reserved. No reuse allowed without permission.

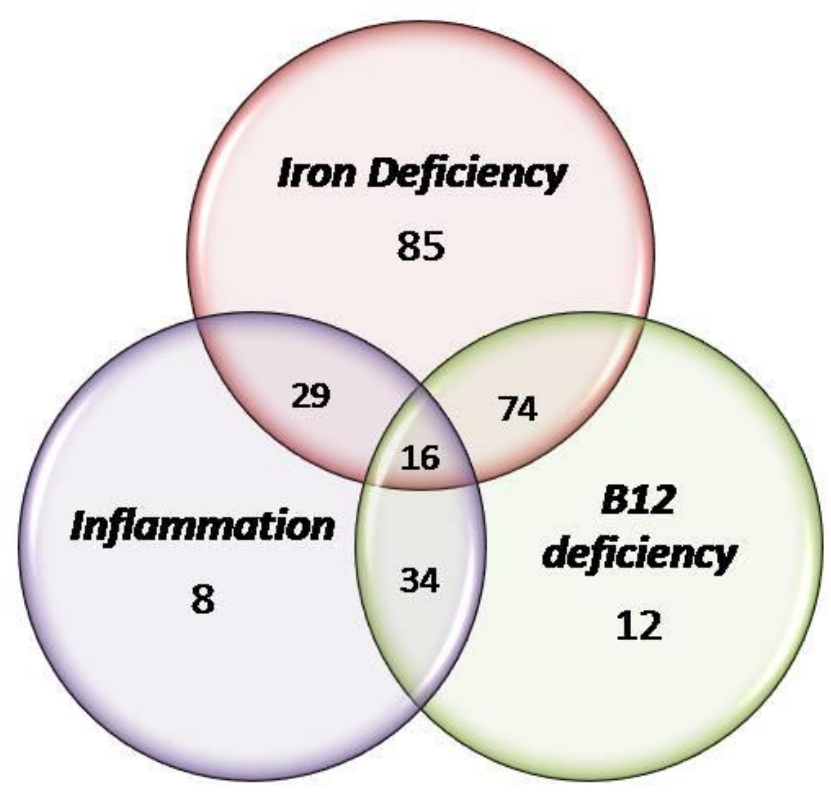

Figure 3. Venn Diagram of Serum Iron, B12 deficiency and Inflammation showing overlap among the three entities. 